\title{
LRP1 in Brain Vascular Smooth Muscle Cells Mediates Local Clearance of Alzheimer's Amyloid- $\beta$
}

\author{
Takahisa Kanekiyo, ${ }^{1}$ Chia-Chen Liu, ${ }^{1,2}$ Mitsuru Shinohara, ${ }^{1}$ Jie $\mathrm{Li},{ }^{1,2}$ and Guojun $\mathrm{Bu}^{1,2}$ \\ ${ }^{1}$ Department of Neuroscience, Mayo Clinic, Jacksonville, Florida 32224, and ${ }^{2}$ Fujian Provincial Key Laboratory of Neurodegenerative Disease and Aging \\ Research, College of Medicine, Xiamen University, Xiamen, Fujian 361005, China
}

\begin{abstract}
Impaired clearance of amyloid- $\beta(\mathrm{A} \beta)$ is a major pathogenic event for Alzheimer's disease (AD). $\mathrm{A} \beta$ depositions in brain parenchyma as senile plaques and along cerebrovasculature as cerebral amyloid angiopathy (CAA) are hallmarks of AD. A major pathway that mediates brain $\mathrm{A} \beta$ clearance is the cerebrovascular system where $\mathrm{A} \beta$ is eliminated through the blood-brain barrier (BBB) and/or degraded by cerebrovascular cells along the interstitial fluid drainage pathway. An A $\beta$ clearance receptor, the low-density lipoprotein receptorrelated protein 1 (LRP1), is abundantly expressed in cerebrovasculature, in particular in vascular smooth muscle cells. Previous studies have indicated a role of LRP1 in endothelial cells in transcytosing A $\beta$ out of the brain across the BBB; however, whether this represents a significant pathway for brain $\mathrm{A} \beta$ clearance remains controversial. Here, we demonstrate that $\mathrm{A} \beta$ can be cleared locally in the cerebrovasculature by an LRP1-dependent endocytic pathway in smooth muscle cells. The uptake and degradation of both endogenous and exogenous A $\beta$ were significantly reduced in LRP1-suppressed human brain vascular smooth muscle cells. Conditional deletion of $L r p 1$ in vascular smooth muscle cell in amyloid model APP/PS1 mice accelerated brain A $\beta$ accumulation and exacerbated A $\beta$ deposition as amyloid plaques and CAA without affecting $\mathrm{A} \beta$ production. Our results demonstrate that LRP1 is a major $\mathrm{A} \beta$ clearance receptor in cerebral vascular smooth muscle cell and a disturbance of this pathway contributes to $\mathrm{A} \beta$ accumulation. These studies establish critical functions of the cerebrovasculature system in $\mathrm{A} \beta$ metabolism and identify a new pathway involved in the pathogenesis of both AD and CAA.
\end{abstract}

\section{Introduction}

Alzheimer's disease (AD) is a progressive neurodegenerative disorder and the most common cause of dementia in elderly population (Hardy and Selkoe, 2002; Goedert and Spillantini, 2006). The amyloid- $\beta$ (A $\beta)$ peptides are cleaved from amyloid precursor protein (Zheng and Koo, 2011). The imbalance between $A \beta$ generation and clearance induces its accumulation, aggregation, and deposition in the brain, which is thought to be an early and main pathogenic event in AD (Hardy and Selkoe, 2002; Goedert and Spillantini, 2006; Koffie et al., 2011). Most cases of AD are sporadic and developed after the age of 65 years. Recent studies have indicated an overall impairment in $\mathrm{A} \beta$ clearance, rather than $\mathrm{A} \beta$ overproduction, in sporadic $\mathrm{AD}$ cases (Mawuenyega et al., 2010). Pathological studies of $A D$ cases show that $A \beta$ deposits in the vascular smooth muscle cell layer of the cerebral blood vessel as cerebral amyloid angiopathy (CAA) as well as senile

\footnotetext{
Received Aug. 20, 2012; revised Sept. 19, 2012; accepted Sept. 22, 2012

Author contributions: T.K. and G.B. designed research; T.K., C.-C.L., M.S., and J.L. performed research; T.K., C.-C.L., M.S., J.L., and G.B. analyzed data; T.K. and G.B. wrote the paper.

This work was supported by NIH Grants R01 AG027924, R01 AG035355, P01 AG030128, and P01 NS074969 (G.B.), a grant from the Alzheimer's Association (G.B.), a fellowship from the American Heart Association (T.K.), a fellowship from The Robert and Clarice Smith and Abigail Van Buren Alzheimer's Disease Research Program (T.K.), Center of Regenerative Medicine Career Development Award in Mayo Clinic (T.K.), and NIH Alzheimer's Disease Research Center Pilot Grant P50 AG16574 (T.K.). We thank Monica Castanedes Casey, Linda Rousseau, Virginia Phillips, and Dr. Dennis Dickson for histology and immunohistochemistry. We also thank Aurelie N'songo and Caroline Stetler for technical assistance and careful readings of this manuscript.

Correspondence should be addressed to Guojun Bu, Department of Neuroscience, Mayo Clinic, 4500 San Pablo Road, Jacksonville, FL 32224. E-mail: bu.guojun@mayo.edu.

DOI:10.1523/JNEUROSCI.3987-12.2012

Copyright $\odot 2012$ the authors $\quad 0270-6474 / 12 / 3216458-08 \$ 15.00 / 0$
}

plaques (Rensink et al., 2003; Revesz et al., 2003). At least, 83\% of autopsy-confirmed AD patients have some degrees of CAA (Ellis et al., 1996). CAA is a major trigger of intracranial hemorrhage (Ellis et al., 1996; Maia et al., 2007) and progressive dementia in the elderly (Rensink et al., 2003; Revesz et al., 2003). A $\beta$ drains through interstitial fluid (ISF) drainage pathways along the vascular smooth muscle cell layer of small and medium-sized arteries, arterioles of the cerebral cortex, and leptomeninges (Weller et al., 1998; Revesz et al., 2003; Thal et al., 2008), where CAA is abundantly detected. Despite increasing interests in understanding the mechanism of $\mathrm{A} \beta$ clearance from the brain, it remains unclear whether $A \beta$ can be cleared locally by the vascular smooth muscle cells while $\mathrm{A} \beta$ flows along the ISF drainage pathway.

The low-density lipoprotein receptor-related protein 1 (LRP1), which is a highly efficient endocytic receptor that binds multiple ligands (Herz and Strickland, 2001; Bu, 2009), mediates A $\beta$ clearance in the brain (Shibata et al., 2000; Deane et al., 2004). LRP1 is abundantly expressed in several different cell types in the brain including neurons (Qiu et al., 1999; Kanekiyo et al., 2011), glia (Wyss-Coray et al., 2003), and vascular smooth muscle cells (Urmoneit et al., 1997; Wilhelmus et al., 2007; Ruzali et al., 2012). Several A $\beta$-binding proteins including apolipoprotein $\mathrm{E}$ (apoE), $\alpha 2$-macroglobulin, and receptor-associated protein (RAP) are ligands of LRP1 (Herz and Strickland, 2001; Bu et al., 2006; Kanekiyo and $\mathrm{Bu}, 2009)$. Previous studies have suggested a role for LRP1 in mediating A $\beta$ transcytosis across the blood-brain barrier (Shibata et al., 2000); however, whether LRP1 is sufficiently expressed in the endothelial cells to mediate $A \beta$ transcytosis remains controversial. Given LRP1 is highly expressed in vascular 
A
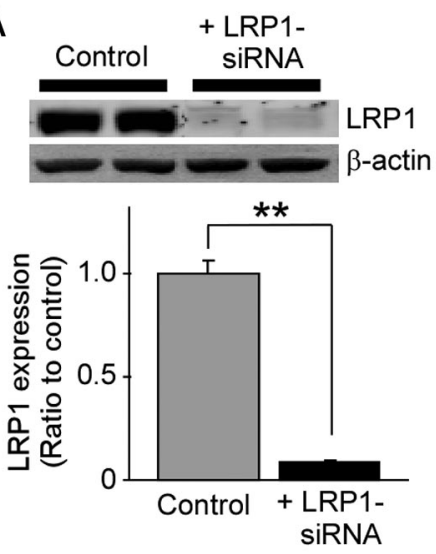

D

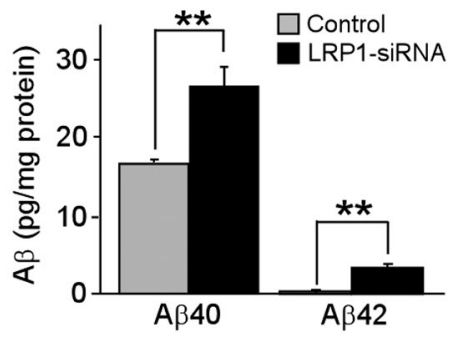

$\mathrm{B}$

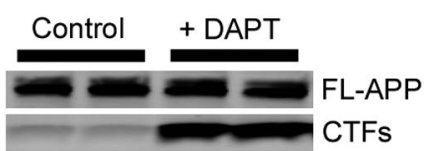

C

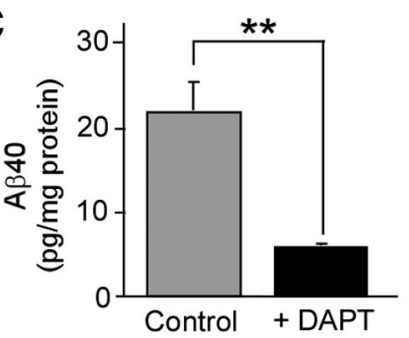

E

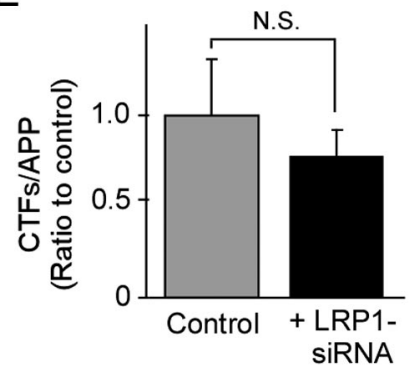

Figure 1. LRP1 mediates A $\beta$ clearance in HBVSMCS. $A$, HBVSMCs were transfected with control or LRP1-siRNA and used for analysis $48 \mathrm{~h}$ after transfection. Western blotting showed that LRP1 expression was suppressed by LRP1-siRNA. B, HBVSMCs were incubated with or without $\gamma$-secretase inhibitor DAPT $(10 \mu \mathrm{m})$ for $24 \mathrm{~h}$, and the levels of full-length APP (FL-APP) and C-terminal fragments of APP (CTFs) were analyzed by Western blot. C, HBVSMCs were incubated for $4 \mathrm{~d}$ in the absence or presence of DAPT (10 $\mu \mathrm{M}$ ), and the concentrations of $A \beta 40$ in the media were analyzed by ELISA. $D$, Control and LRP1-suppressed HBVSMCs were incubated for $4 d$, and the concentrations of endogenous $A \beta 40$ and $A \beta 42$ in the media were quantified by ELISA. $E$, To examine whether LRP1 knockdown in HBVSMCs affects APP processing, CTFs were analyzed by Western blot and quantified. Data are plotted as mean $\pm S D(n=3) .{ }^{* *} p<0.01$. N.S., Not significant.

smooth muscle cell layer of the cerebral blood vessels (Zlokovic, 2011) and its expression is vastly decreased in the vasculature of AD brains with CAA (Bell et al., 2009), we sought to examine whether LRP1 in vascular smooth muscle cells mediates local clearance of $\mathrm{A} \beta$, and whether a disturbance of this pathway would exacerbate the formation of CAA.

\section{Materials and Methods}

Reagents. A $\beta 40, \mathrm{~A} \beta 42,5(6)$-carboxyfluorescein (FAM)-A $\beta 40$, and FAM$A \beta 42$ were purchased from AnaSpec. Dry peptide was pretreated with neat trifluoroacetic acid, distilled under nitrogen, washed with $1,1,1,3,3,3$ hexafluoro-2-propanol, distilled under nitrogen, and stored at $-20^{\circ} \mathrm{C}$. A $\beta$ peptides were freshly dissolved in dimethyl sulfoxide at $200 \mu \mathrm{M}$ for each experiment. Rabbit polyclonal anti-LRP1 antibody was produced in our laboratory (Liu et al., 2007). Anti-APP C-terminal, sAPP $\alpha$, and $\operatorname{sAPP} \beta$ antibodies were purchased from IBL. DAPT, pepstatin, leupeptin, and E-64d were purchased from Sigma-Aldrich.

Cell culture and LRP1 knockdown by siRNA. Human brain vascular smooth muscle cells (HBVSMCs) were purchased from ScienCell and cultured under standard culture conditions according to the manufacturer's protocol. Knockdown of LRP1 was performed as described previously (Li et al., 2003). Single-stranded, LRP1-specific, sense and antisense RNA oligonucleotides were synthesized by Ambion. Cells were transfected with siRNA (100 nM) using Lipofectamine 2000 (Invitrogen) according to the manufacturer's specifications and used for analysis $48 \mathrm{~h}$ after transfection.

Animals and tissue preparation. Vascular smooth muscle cell-specific LRP1-KO mice ( $\operatorname{smLrp1^{-1-}}$ ) were generated by breeding the Lrp1 floxed mice (Rohlmann et al., 1998) with sm $22 \alpha$-driven Cre recombinase mice (Holtwick et al., 2002). Littermates of male $\operatorname{smLrp1} 1^{-/-}$mice (LRP1 flox/flox, sm $\left.22 \alpha-C r e^{+/-}\right)$or controls (LRP1 flox/flox, $\operatorname{sm} 22 \alpha-\mathrm{Cre}^{-/-}$) were used. Furthermore, amyloid model APP/PS1 mice (Borchelt et al., 1997) were crossed with $\operatorname{smL} L p 1^{-/-}$mice. Littermates of male APP/PS1-Tg mice (APP/PS1) and APP/ PS1-Tg mice lacking LRP1 in vascular smooth muscle cells (APP/PS1; smLrp1 $1^{-1-}$ ) were used for analysis. After perfusion with PBS, brain tissues were dissected and kept frozen at $-80^{\circ} \mathrm{C}$ until further analysis. Some brain tissues were fixed in $10 \%$ neutralized formalin for histological analysis. All animal procedures were approved by the Animal Study Committee at Mayo Clinic and in accordance with the regulations of the American Association for the Accreditation of Laboratory Animal Care.

Isolation of brain microvessels. Brain microvessels were isolated as previously described (Shinohara et al., 2010). In brief, mouse brains were homogenized in DMEM and resuspended with $17 \%$ dextran (Sigma-Aldrich). Following centrifugation at $10,000 \times g$ for 15 min at $4^{\circ} \mathrm{C}$, the pellets were suspended with DMEM containing $10 \%$ fetal bovine serum (FBS) and filtered through sterilized glass beads (425-600 $\mu \mathrm{m}$, acid-washed; SigmaAldrich) on a $70 \mu \mathrm{m}$ nylon cell strainer (BD Biosciences). After transfer onto a plastic dish with DMEM containing 10\% FBS, dissociated vessels from glass beads were collected and lysed in RIPA buffer.

Confocal microscopy. Cells were cultured on eight-well slides (Lab-Tek II Chamber SlideTM System; Nalge Nunc International) at $37^{\circ} \mathrm{C}$ for at least $24 \mathrm{~h}$ before experiments. After incubation with FAM-A $\beta 40$ or FAM-A $\beta 42$ $(500 \mathrm{~nm})$ at $37^{\circ} \mathrm{C}$ for $8 \mathrm{~h}$, fluorescence associated with $\mathrm{A} \beta$ was observed by confocal laserscanning fluorescence microscopy (model LSM 510 invert; Carl Zeiss). LysoTracker (50 nM; Invitrogen) was added $30 \mathrm{~min}$ before confocal imaging. Isolated mouse leptomeningeal arteries were placed on coverslip, fixed in $4 \%$ paraformaldehyde, permeabilized with PBS containing $0.2 \%$ Triton X-100, and incubated with rabbit polyclonal anti-LRP1 antibody in PBS containing $1 \%$ bovine serum albumin at $4^{\circ} \mathrm{C}$ for overnight followed by incubation with a goat anti-rabbit Alexa Fluor 488 secondary antibody (Invitrogen) and Alexa Fluor 568 phalloidin (F-actin marker; Invitrogen) for confocal microscopy analysis.

Fluorescence-activated cell sorter-based internalization assays. A $\beta$ internalization was analyzed by fluorescence-activated cell sorter (FACS) as previously described (Kanekiyo et al., 2011). Briefly, cells were incubated with FAM-A $\beta 40$ (500 nM) or FAM-A $\beta 42(500 \mathrm{~nm})$ at $37^{\circ} \mathrm{C}$ for $24 \mathrm{~h}$ in DMEM with $10 \% \mathrm{FBS}$ for internalization assay. Cells were removed from the plate using Cell Dissociation Solution (Sigma-Aldrich) and incubated with Pronase $\left(0.5 \mathrm{mg} / \mathrm{ml}\right.$; Boehringer Mannheim) at $4^{\circ} \mathrm{C}$ for 20 min. Cells were then washed and resuspended in PBS containing 1.5\% FBS, $1 \%$ sodium azide, and $1 \%$ paraformaldehyde. Cells $\left(1 \times 10^{4}\right)$ from each sample were analyzed for fluorescence on a BD FACSCalibur machine (BD Biosciences). Unstained cells without any exposure to fluorescence were used as a control for background fluorescence.

$A \beta$ ELISA. For measurements of endogenous $\mathrm{A} \beta$ from mouse brain, samples were homogenized in diethylamine (Shinohara et al., 2010). For measurements of $A \beta$ in APP/PS1 mouse brain, samples were sequentially homogenized in Tris-buffered saline (TBS), TBS buffer containing 1\% Triton X-100 and $5 \mathrm{~m}$ guanidine in $50 \mathrm{~mm}$ Tris- $\mathrm{HCl}, \mathrm{pH} 8.0$ (Youmans et al., 2011). The $A \beta$ levels in culture media from HBVSMCs were directly analyzed. Cell-associated $A \beta$ levels were analyzed after dissolved in guanidine. To assess human $A \beta 40$ and human $A \beta 42$, mouse monoclonal antibodies 2G3 recognizing human/mouse $\mathrm{A} \beta 33-40$ and 21F12 recognizing human/mouse $\mathrm{A} \beta 33-42$, respectively, were used as coating antibodies and a 
biotinylated human $\mathrm{A} \beta$-specific antibody 3D6 recognizing human $A \beta 1-6$ was used for detection. Mouse A $\beta 40$ was assessed using a 266 antibody as a coating antibody and a biotinylated 2G3 antibody recognizing human/mouse $\mathrm{A} \beta 13-28$ as the detecting antibody. Mouse $\mathrm{A} \beta 42$ was assessed using a 266 antibody as a coating antibody and a biotinylated 21F12 antibody as the detecting antibody. After incubation with horseradish peroxidase streptavidin-streptavidin (Vector), the plate was developed with tetramethylbenzidine (Sigma-Aldrich) and read at 650 $\mathrm{nm}$ with a Bio-Tek 600 plate reader (Nalge Nunc International). Those anti- $\mathrm{A} \beta$ antibodies were kindly provided by Dr. Ronald B. DeMattos (Lilly Research Laboratories, Indianapolis, IN), and the ELISA systems have been described in previous publications (Zerbinatti et al., 2004; Liu et al., 2010).

Immunohistochemical imaging and image processing. Paraffin-embedded sections were immunostained using pan- $\mathrm{A} \beta \mathrm{Ab}$ 33.1.1 (human $A \beta 1-16$ specific) or anti-glial fibrillary acidic protein (GFAP) (Sigma-Aldrich), and visualized through the Dako Envision Plus visualization system (Dako) (Chakrabarty et al., 2010). Immunohistochemically stained sections were captured using the Scanscope XT image scanner (Aperio Technologies) and analyzed using the ImageScope program (Chakrabarty et al., 2010). The final images and layouts were created using Photoshop CS2 (Adobe). Immunostained total A $\beta$ plaque burdens in the cortex and CAA formation on leptomeningeal arteries were calculated using the Positive Pixel Count program available with the Imagescope software (Aperio Technologies). All of the above analyses were performed in a blinded manner.

Western blotting. Samples were lysed in PBS containing 1\% Triton X-100 and protease inhibitor mixture from Roche or RIPA buffer. Protein concentration was determined in each sample using a Protein Assay kit (Bio-Rad). An equal amount of sample protein was used for SDS-PAGE. Immunoreactive bands were detected and quantified using Odyssey Infrared Imaging System (LI-COR Biosciences).

Reverse transcription and PCR. Total RNA was isolated from tissues or cells using RNeasy Mini Kit (QIAGEN) and subjected to DNase I digestion to remove contaminating genomic DNA. Total RNA was dissolved in nucleasefree water and stored at $-80^{\circ} \mathrm{C}$. Reverse transcription was performed using a SuperScript II RNase H-reverse transcriptase (Invitrogen), and the reaction mix was subjected to quantitative real-time PCR to detect levels of the corresponding mouse actin, neprilysin, IDE, MMP2, and MMP9. The set of actin primers (QIAGEN) was used as an internal control for each specific gene amplification. The relative levels of expression were quantified and analyzed by using Bio-Rad iCycler iQ software (Bio-Rad). The real-time value for each sample was averaged and compared using the CT method, where the amount of target RNA $\left(2^{-\Delta \Delta \mathrm{CT}}\right)$ was normalized to the endogenous actin reference $(\Delta C T)$ and related to the

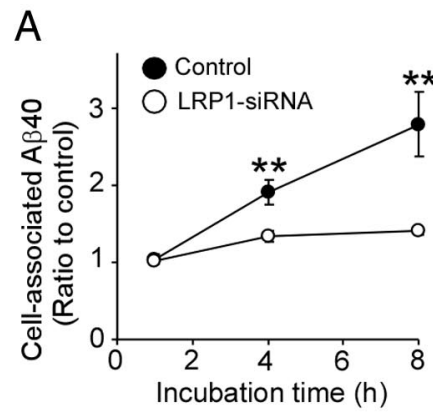

C

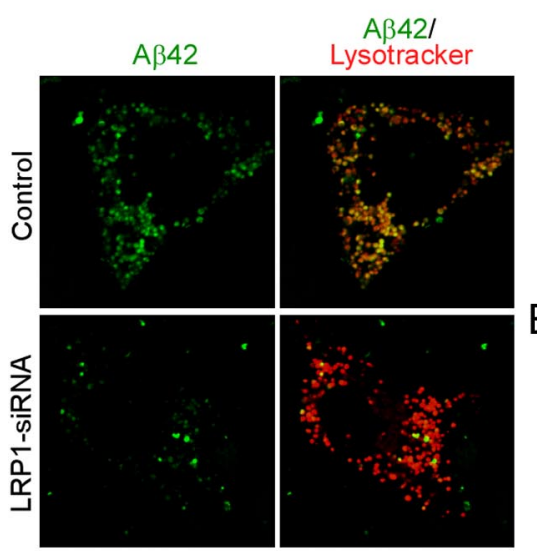

B

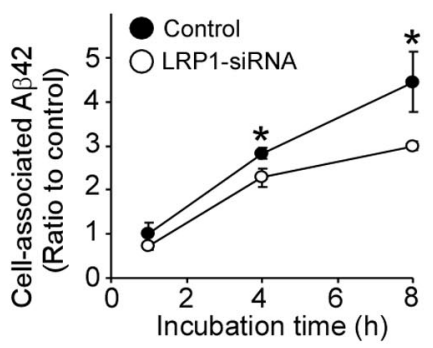

D

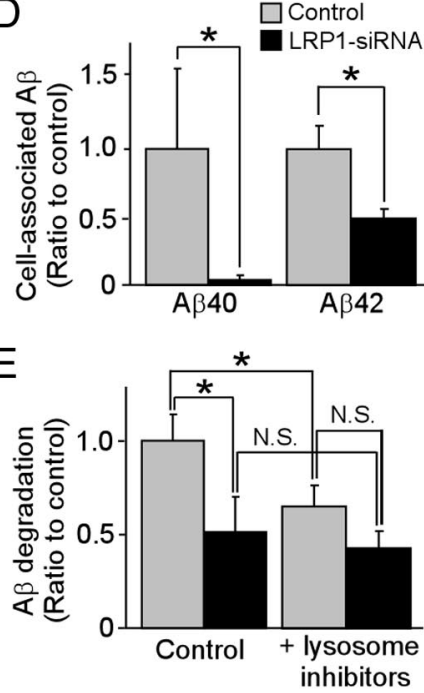

Figure 2. LRP1 mediates $A \beta$ uptake and cellular clearance in HBVSMCS. $\boldsymbol{A}, \boldsymbol{B}$, The levels of cell-internalized $A \beta 40(\boldsymbol{A})$ and $A \beta 42(B)$ were analyzed by FACS in control and LRP1-suppressed HBVSMCs after incubation with FAM-labeled $A \beta(500$ $\mathrm{nm}$ ) for 1,4 , and $8 \mathrm{~h}$. C, Subcellular localization of internalized FAM-A $\beta 42$ and its colocalization with lysosomal marker were observed by confocal microscopy in control and LRP1-suppressed HBVSMCS. D, Control and LRP1-suppressed HBVSMCS were incubated with unlabeled $A \beta 40$ or $A \beta 42$ (10 nm each) for $4 \mathrm{~h}$, and cell-associated $A \beta$ was quantified by ELISA. $\boldsymbol{E}$ Control and LRP1-suppressed HBVSMCs were incubated with $1 \mu \mathrm{m} \mathrm{A} \beta 40(1 \mu \mathrm{m})$ for $1 \mathrm{~h}$ followed by additional incubation for $4 \mathrm{~h}$ in the presence or absence of lysosomal inhibitors (pepstatin, $1 \mu \mathrm{m}$; leupeptin, $50 \mu \mathrm{m} ; \mathrm{E}-64 \mathrm{~d}, 15 \mu \mathrm{m}$ ) without $\mathrm{A} \beta$. Disappearance of cell-associated A $\beta$ detected by ELISA was defined as degraded A $\beta$. Data are plotted as mean \pm SD $(n=$ 3). ${ }^{*} p<0.05 ;{ }^{* *} p<0.01$. N.S., Not significant.

A

$\mathrm{B}$
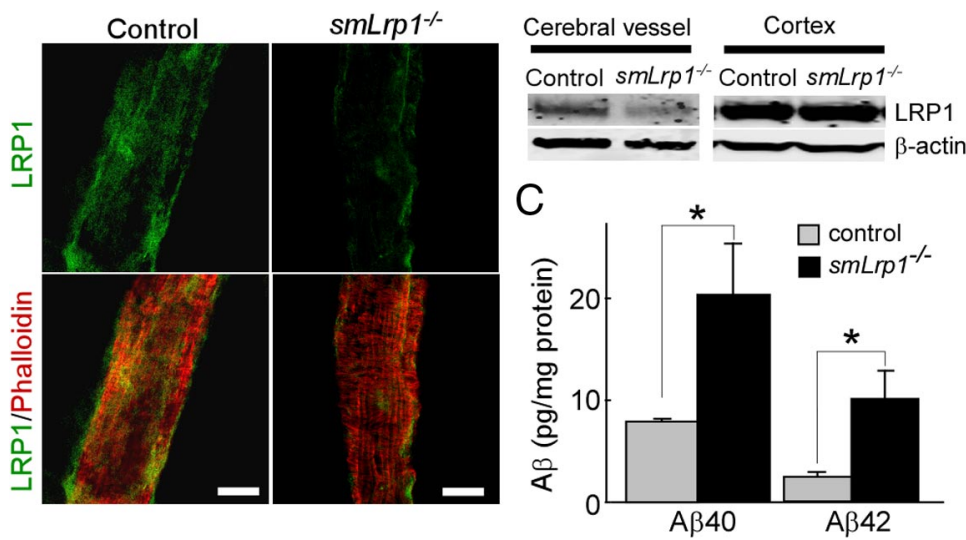

Figure 3. LRP1 deletion in vascular smooth muscle cells in mouse brains leads to increased endogenous $A \beta$ levels. $A$, Leptomeningeal arteries isolated from control and $\mathrm{smLrp1} 1^{-/-}$mice were stained with LRP1 antibody and phalloidin (F-actin marker). Scale bar, $50 \mu \mathrm{m}$. B, LRP1 expression in isolated vessels and cortex from control and smLrp $1^{-1-}$ mice (4-5 months of age) detected by Western blot. $C$, Mouse endogenous $A \beta 40$ and $A \beta 42$ levels in the brains of control and $s m L r p 1^{-\prime-}$ mice analyzed by ELISA. Data are plotted as mean \pm SEM $(n=6) .{ }^{*} p<0.05$. 
A
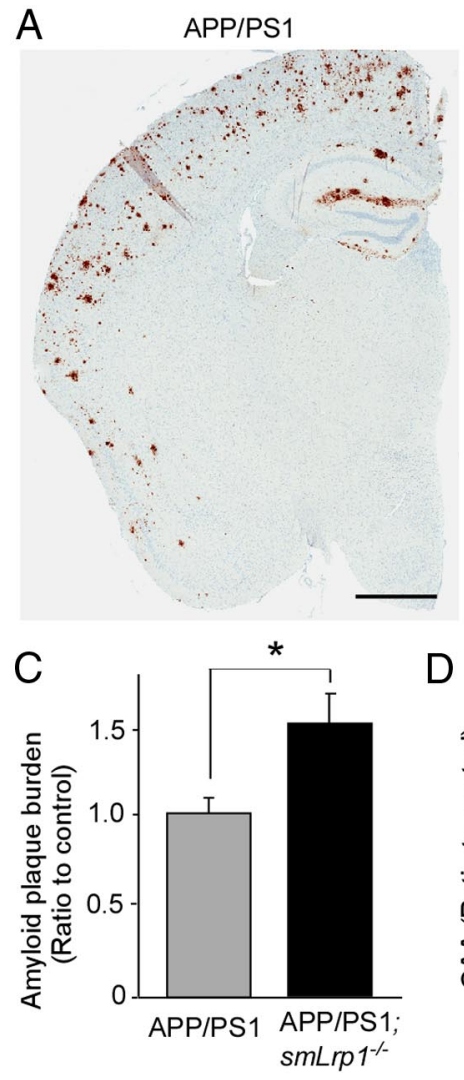

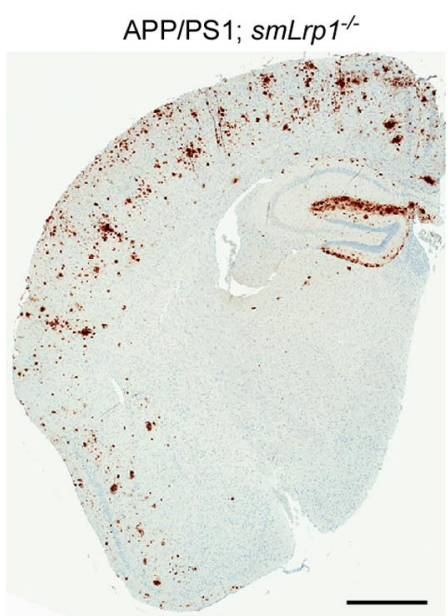

B

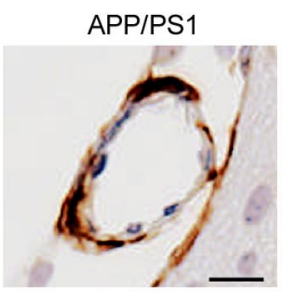

APP/PS1; $s m L r p 1^{-/-}$

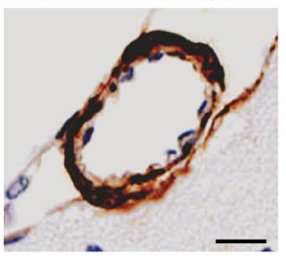

$\mathrm{D}$

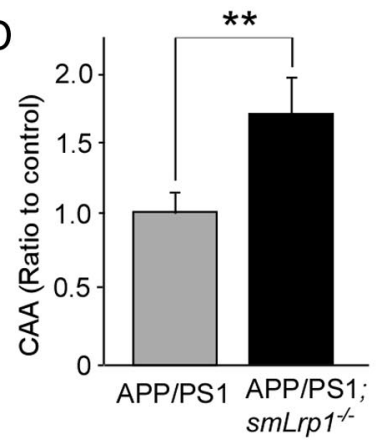

$\mathrm{E}$

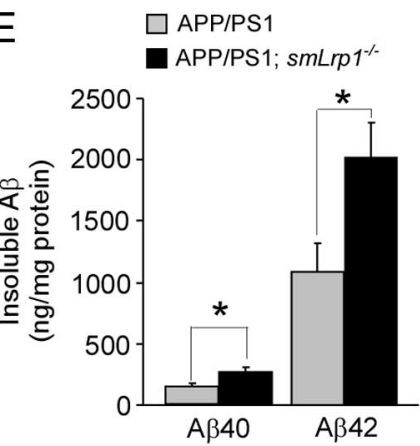

Figure 4. LRP1 deletion in vascular smooth muscle cells in APP/PS1 amyloid model mice exacerbates A $\beta$ deposition as amyloid plaques and CAA. $A$, A $\beta$ depositions in brain sections from control APP/PS1 and APP/PS1; smLrp1 ${ }^{-1-}$ mice (13-14 months of age) were immunostained with a pan- $A \beta$ antibody. Scale bar, $1 \mathrm{~mm}$. $B$, Immunostaining of $A \beta$ deposition along leptomeningeal arteries as CAA in control APP/PS1 and APP/PS1; smLrp1 ${ }^{-1-}$ mice. Scale bar, $20 \mu \mathrm{m}$. C, D, Amyloid plaque burdens in cortex (C) and CAA formation in leptomeningeal arteries (D) were quantified after scanning $A \beta$ immunostaining by the Positive Pixel Count program (Aperio Technologies). $\boldsymbol{E}$, The concentrations of insoluble $A \beta 40$ and $A \beta 42$ levels in the cortex from control APP/PS1 and APP/PS1; smLrp1 ${ }^{-1-}$ mice analyzed by ELISA at 13-14 months of age. Data are plotted as mean \pm SEM $(n=5) .{ }^{*} p<0.05 ;{ }^{* *} p<0.01$.

amount of target gene in tissue cells, which was set as the calibrator at 1.0. The primers used to amplify target genes by RT-PCR and quantitative PCR were as follows: mouse neprilysin-F ( $5^{\prime}$-GCA GCC TCA GCC GAA ACT AC-3'), mouse neprilysin-R (5'-CAC CGT CTC CAT GTT GCA GT-3'); mouse insulin-degrading enzyme (IDE)-F (5'-ACT AAC CTG GTG GTG AAG-3'), mouse IDE-R (5'-GGT CTG GTA TGG GAA ATG$\left.3^{\prime}\right)$; mouse metalloproteinase 2 (MMP2)-F (5'-GTC GCC CCT AAA ACA GAC AA-3'), mouse MMP2-R (5'-GGT CTC GAT GGT GTT CTG GT-3'); and mouse MMP9-F (5'-CGT CGT GAT CCC CAC TTA CT$3^{\prime}$ ), mouse MMP9-R (5'-AAC ACA CAG GGT TTG CCT TC-3').

Statistical analysis. All quantified data represent an average of samples. Statistical significance was determined by two-tailed paired Student's $t$ test, and $p<0.05$ was considered significant.

\section{Results}

LRP1 mediates A $\beta$ metabolism in human brain vascular smooth muscle cell

To determine the roles of LRP1 in A $\beta$ metabolism in vascular smooth muscle cells, we first examined whether LRP1 knockdown by siRNA (Fig. $1 A$ ) affects the endogenous $\mathrm{A} \beta$ levels produced by HBVSMCs, which express an abundance of APP (Fig. $1 B$ ) and produce $\mathrm{A} \beta$ (Fig. $1 C$ ). ELISA revealed that LRP1 knockdown significantly increased endogenous $A \beta 40$ and $A \beta 42$ levels in the media compared with controls (Fig. $1 D$ ) without affecting APP processing (Fig. 1E). We sought to further assess whether LRP1 mediates cellular $A \beta$ uptake and degradation by incubating LRP1-suppressed HBVSMCs with FAM-labeled A $\beta 40$ and $A \beta 42$. The amounts of cell-associated $A \beta$ were detected by FACS (Fig. $2 A, B)$. The results showed that cell-associated $\mathrm{A} \beta 40$ and $\mathrm{A} \beta 42$ levels in HBVSMCs were increased in a time-dependent manner, and that knockdown of LRP1 expression significantly decreased $\mathrm{A} \beta$ uptake following 4 and $8 \mathrm{~h}$ of $\mathrm{A} \beta$ incubation (Fig. $2 A, B$ ). Similar results were obtained using unlabeled $A \beta$ and detection by ELISA (Fig. 2D). Consistent with our FACS and ELISA results, we observed less internalized A $\beta$ in LRP1-suppressed HBVSMCs by confocal microscopy (Fig. $2 C$ ). As internalized $\mathrm{A} \beta$ was detected primarily in the lysosomal compartments (Fig. 2C), we examined whether $\mathrm{A} \beta$ is degraded via the lysosomal pathway. HBVSMCs were incubated with $A \beta 40$ for $1 \mathrm{~h}$, followed by an additional incubation of $4 \mathrm{~h}$ in the presence or absence of lysosomal inhibitors without $\mathrm{A} \beta$. When disappearance of cellassociated $\mathrm{A} \beta$ detected by ELISA was defined as degraded $\mathrm{A} \beta$, LRP1 deletion, as well as lysosomal inhibitors, significantly suppressed $\mathrm{A} \beta$ degradation in HBVSMCs (Fig. $2 E$ ). However, $\mathrm{A} \beta$ degradation was not suppressed by lysosomal inhibitors upon LRP1 deletion (Fig. $2 E$ ), suggesting that $\mathrm{A} \beta$ clearance in HBVSMCs by the lysosomes depends on the presence of LRP1. These results suggest that LRP1 likely mediates $A \beta$ clearance through the lysosomal degradation pathway in HBVSMCs.

\section{LRP1 deletion in vascular smooth muscle cells in mice leads to $\mathrm{A} \boldsymbol{\beta}$ accumulation}

To examine the effect of LRP1 deletion in vascular smooth muscle cells on $\mathrm{A} \beta$ clearance in vivo, we generated vascular smooth muscle cell-specific LRP1-KO mice $\left(\operatorname{smLrp1} 1^{-/-}\right)$by breeding the Lrp1 floxed mice (Rohlmann et al., 1998) with sm22 $\alpha$-driven Cre 
recombinase mice (Holtwick et al., 2002). The leptomeningeal artery isolated from 4-month-old $\operatorname{smLrp1} 1^{-1-}\left(\operatorname{Lrp} 1^{\text {flox/flox }}\right.$, $\left.\operatorname{sm} 22 \alpha-C r e^{+/-}\right)$mice or control ( $\left.\operatorname{Lrp} 1^{\text {flox/flox }}, \operatorname{sm} 22 \alpha-C r e^{-1-}\right)$ mice were stained with LRP1-antibody and phalloidin (F-actin marker) and analyzed by confocal microscopy. Immunostaining clearly showed that the expression of LRP1 was deleted in leptomeningeal artery from smLrp1 $1^{-1-}$ mice (Fig. $3 A$ ). Western blotting also confirmed that LRP1 level in isolated brain vessels from smLrp1 $1^{-1-}$ mice was mostly deleted, while there was no difference in the LRP1 levels in cortex between control and $\operatorname{smLrp1} 1^{-1-}$ mice (Fig. $3 B$ ). ELISA showed that endogenous levels of both $\mathrm{A} \beta 40$ and $\mathrm{A} \beta 42$ are significantly increased in the brains of smLrp1 $1^{-1-}$ mice compared with their littermate controls (Fig. $3 C)$. These results indicate that LRP1 in vascular smooth muscle cells mediates $\mathrm{A} \beta$ metabolism, and a disturbance of this pathway is sufficient to induce $A \beta$ accumulation in the brain.

\section{LRP1 deletion in vascular smooth muscle cells in amyloid model mice exacerbates $A \boldsymbol{\beta}$ deposition}

To further confirm the role for LRP1 in vascular smooth muscle cells, A $\beta$ metabolism, we crossed smLrp1 $1^{-1-}$ mice with amyloid model APP/PS1 mice (Borchelt et al., 1997). We compared amyloid plaque deposition and CAA by immunostaining for $\mathrm{A} \beta$ between littermates of APP/PS1 mice without (APP/PS1) or with LRP1 deletion (APP/PS1; smLrp1 $1^{-1-}$ ) in vascular smooth muscle cells. We found that $\mathrm{A} \beta$ deposition in the brains of APP/PS1; smLrp1 $1^{-1-}$ mice was significantly higher than that of control APP/PS1 mice at 13-14 months of age (Fig. $4 A, B$ ). In addition to the cortical parenchyma, $\mathrm{A} \beta$ deposition manifested in cortical vessels as CAA, which was also increased in the APP/PS1; smLrp1 $1^{-1-}$ mice (Fig. $4 C, D$ ). Consistent with increased $\mathrm{A} \beta$ deposition, the concentrations of insoluble $A \beta 40$ and $A \beta 42$ in the guanidine fractions were significantly higher in the APP/PS1; smLrp1 $1^{-1-}$ mice (Fig. $4 E$ ). The effects of LRP1 deletion on A $\beta$ accumulation is likely age dependent as we found no significant differences in the concentrations of insoluble $A \beta 40$ (582 \pm 68 vs $558 \pm 99 \mathrm{pg} / \mathrm{mg}$ protein) and $\mathrm{A} \beta 42(4.83 \pm 0.71 \mathrm{vs} 4.07 \pm 1.40$ $\mathrm{ng} / \mathrm{mg}$ protein) (mean $\pm \mathrm{SEM} ; n=4)$ between control APP/PS1 and APP/PS1; smLrp1 ${ }^{-1-}$ mice at 3 months of age.

To examine whether LRP1 deletion in vascular smooth muscle cells affects APP processing, APP derivatives in both APP/PS1 and APP/PS1; smLrp1 $1^{-1-}$ mice at 13-14 months of age were analyzed by Western blotting (Fig. $5 A$ ). There were no significant differences in the level of full-length APP (Fig. 5B), CTF $\alpha$ (Fig. 5C), CTF $\beta$ (Fig. $5 D$ ), sAPP $\alpha$ (Fig. $5 E$ ), and sAPP $\beta$ (Fig. $5 F$ ) between APP/PS1 and APP/PS1; smLrp1 ${ }^{-1-}$ mice. Next, we analyzed the mRNA levels of neprilysin (Fig. 6A), IDE (Fig. 6B), MMP2 (Fig. 6C), and MMP9 (Fig. 6D), which are major $\mathrm{A} \beta$ degrading enzymes in the brain, in the cortex of control and smLrp1 ${ }^{-1-}$ mice. RT-PCR showed no significant differences in the mRNA levels of these enzymes in our experimental mice. Together, these results indicate that LRP1 deletion in vascular smooth muscle cells exacerbates $\mathrm{A} \beta$ deposition through a disturbance of lysosomal-mediated $\mathrm{A} \beta$ clearance along brain vasculature without affecting APP processing or the expression levels of major $A \beta$-degrading enzymes in amyloid model mice.

LRP1 deletion in vascular smooth muscle cells in amyloid model mice exacerbates astrogliosis

Abnormal activation of astrocytes is observed in the brains of AD patients and APP transgenic mouse models (Wyss-Coray, 2006). To examine the extent of astrogliosis, brain sections were stained
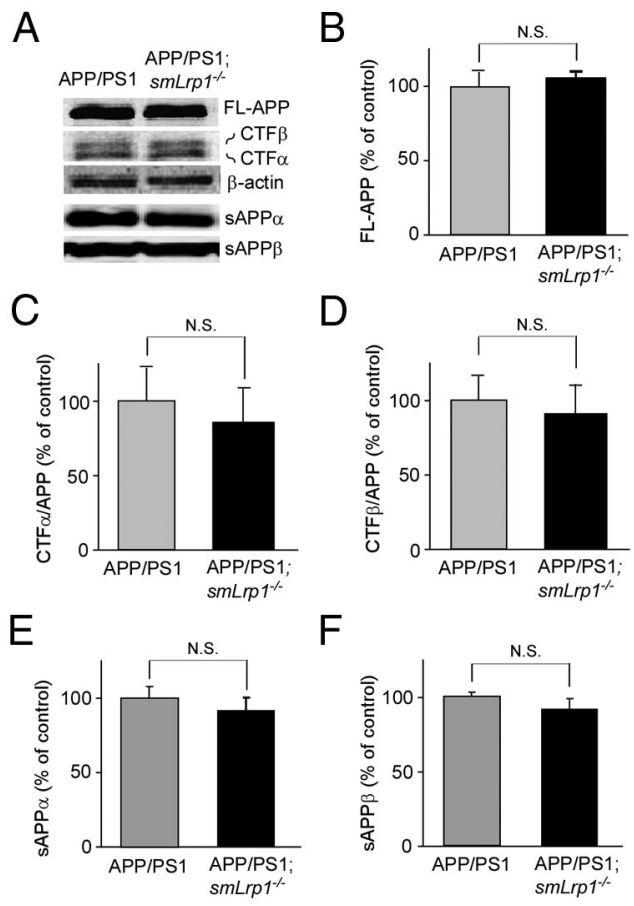

Figure 5. LRP1 deletion in vascular smooth muscle cells does not affect APP processing in APP/PS1 mice. APP and its processing products in both APP/PS1 and APP/PS1; $s m L r p 1^{-1-}$ mice at the age of 13-14 months were analyzed by Western blot $(\boldsymbol{A})$. There were no significant differences in the levels of full-length $\operatorname{APP}(\boldsymbol{B}), \operatorname{CTF} \alpha(\boldsymbol{C}), \operatorname{CTF} \beta(\boldsymbol{D})$, SAPP $\alpha(\boldsymbol{E})$, and SAPP $\beta(\boldsymbol{F})$ between the two groups of mice. Data are plotted as mean \pm $\operatorname{SEM}(n=5)$. N.S., Not significant.
A

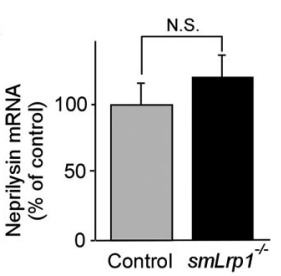

C

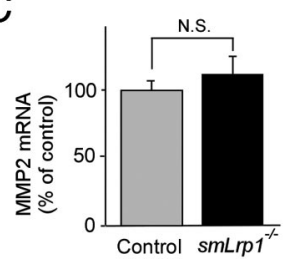

$B$

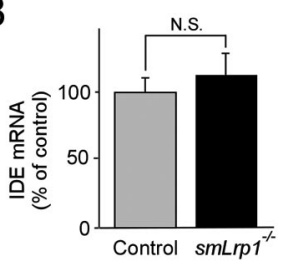

$\mathrm{D}$

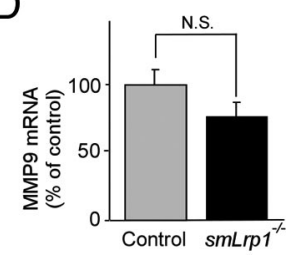

Figure 6. LRP1 deletion in vascular smooth muscle cells does not affect the expression levels of major $A \beta$-degrading enzymes. The mRNA levels of neprilysin $(\boldsymbol{A}), \operatorname{IDE}(\boldsymbol{B}), \operatorname{MMP2}(\boldsymbol{C})$, and $\operatorname{MMP9}(\boldsymbol{D})$ in the cortex from control and $s m L r p 1^{-1-}$ mice were quantified by RT-PCR at the age of 12 months. Data are plotted as mean \pm SEM $(n=6)$. N.S., Not significant.

with anti-GFAP antibody to quantify the extent of astrogliosis (Fig. 7A). The immunostaining for GFAP clearly demonstrated that activation of astrocytes was enhanced in the brains of APP/ PS1; smLrp1 $1^{-1-}$ mice compared with those of APP/PS1 mice at the age of 1 year (Fig. 7A). When GFAP levels in cortex (Fig. 7B) of those mice were analyzed by Western blotting, GFAP levels were also significantly increased in APP/PS1; smLrp1 ${ }^{-1-}$ mice. These findings demonstrate that the exacerbated $\mathrm{A} \beta$ deposition by LRP1 deletion in vascular smooth muscle cells leads to accelerate activation of astrocytes. 
A

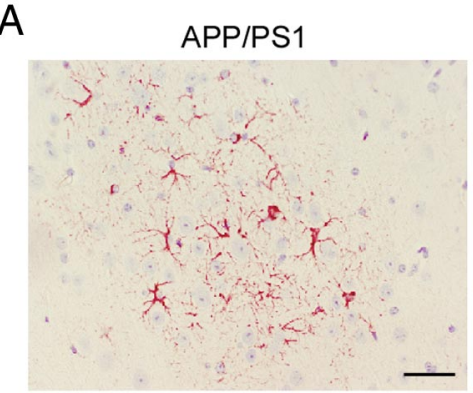

B
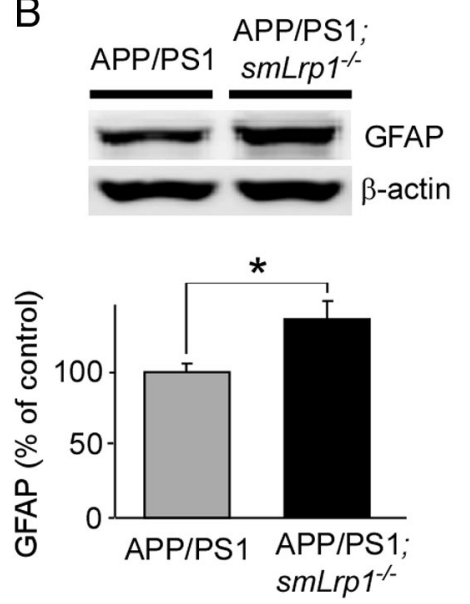

APP/PS1; smLrp1/-

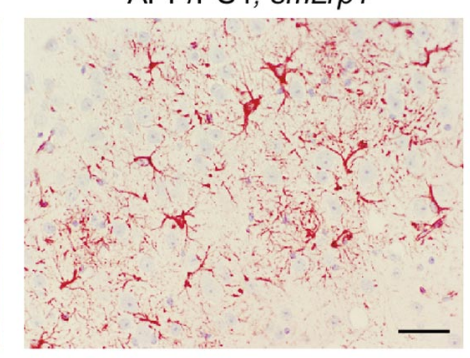

C
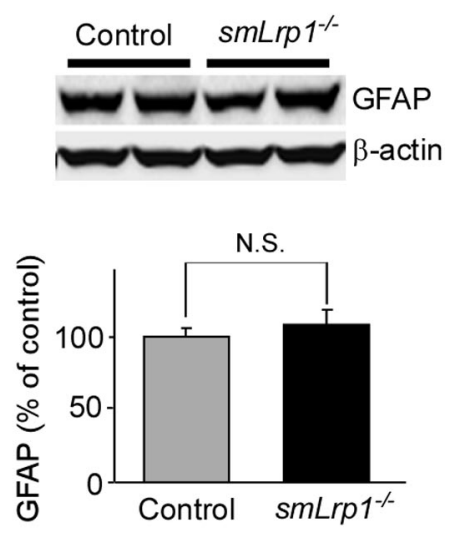

Figure 7. LRP1 deletion in vascular smooth muscle cells in APP/PS1 mice exacerbates astrogliosis. $\boldsymbol{A}$, Astrogliosis in brain sections from control APP/PS1 and APP/PS1; smLrp1 ${ }^{-/-}$mice (13-14 months of age) detected with a GFAP antibody. Scale bar, $50 \mu \mathrm{m}$. B, GFAP levels in the cortices of control APP/PS1 and APP/PS1; smLrp1 ${ }^{-1-}$ mice quantified by Western blotting at 13-14 months of age. The activation of astrocytes is enhanced in the cortex of APP/PS1; smLrp1 $1^{-1-}$ mice compared with control APP/PS1 mice. C, When GFAP levels in cortices of control and smLrp ${ }^{-1}$ - mice were analyzed at the age of 12 months, there was no significant difference between those mice. Data are plotted as mean $\pm \operatorname{SEM}(n=5)$. ${ }^{*} p<0.05$. N.S., Not significant.

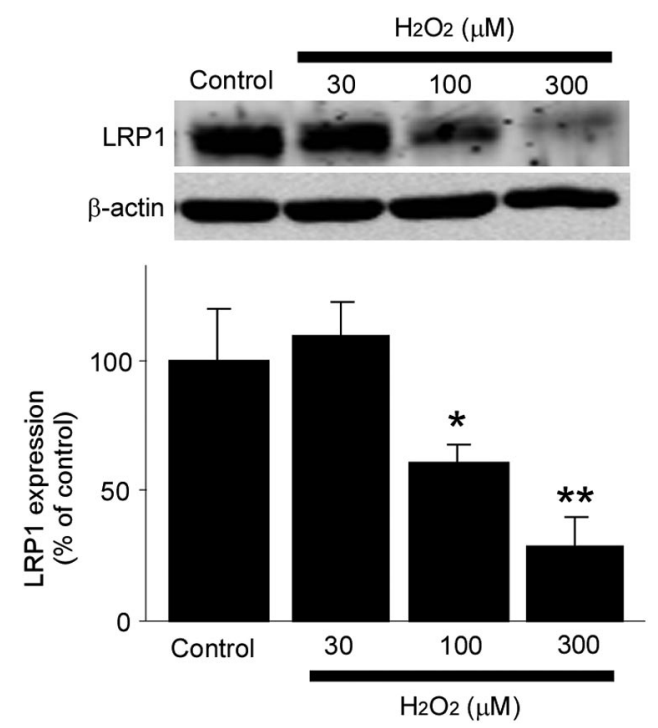

Figure 8. Hydrogen peroxide downregulates LRP1 levels in HBVSMCs. LRP1 expression levels in HBVSMCs after incubation with increasing concentrations of hydrogen peroxide $\left(\mathrm{H}_{2} \mathrm{O}_{2}\right)$ for $24 \mathrm{~h}$ and analyzed by Western blot. $\mathrm{H}_{2} \mathrm{O}_{2}$ significantly suppressed LRP1 levels in a concentration-dependent manner. Data are plotted as mean \pm SD $(n=3) .{ }^{*} p<0.05$; ${ }^{* *} p<0.01$.

\section{Discussion}

In this study, we have demonstrated a critical role of LRP1 in vascular smooth muscle cells in mediating brain $\mathrm{A} \beta$ clearance. Importantly, we showed that deletion of a single $\mathrm{A} \beta$ metabolic receptor in vascular smooth muscle cells is sufficient to impair brain $\mathrm{A} \beta$ clearance in an amyloid mouse model. We also report for the first time, to our knowledge, that vascular smooth muscle cells in the brain are capable of mediating local clearance of $\mathrm{A} \beta$.

One of the major $\mathrm{A} \beta$ clearance pathways in the brain is through proteolytic degradation by $A \beta$-degrading enzymes including neprilysin, IDE, and MMPs (Bu, 2009). Neprilysin levels are decreased in vascular smooth muscle cells in $\mathrm{AD}$ patients, which are correlated with CAA formation (Miners et al., 2006). Cellular A $\beta$ clearance is also a major $\mathrm{A} \beta$ clearance pathway. For example, astrocytes (WyssCoray et al., 2003; Koistinaho et al., 2004) and microglia (Wyss-Coray et al., 2001; El Khoury and Luster, 2008; Luo et al., 2010) can degrade $A \beta$ to eliminate it from the brain. In addition to brain-resident cells, perivascular macrophages also appear to play a role in the degradation of $A \beta$ and CAA formation (Hawkes and McLaurin, 2009). A $\beta$ is also directly cleared to peripheral through the blood-brain barrier (Bell et al., 2007; Zlokovic, 2011). Despite the facts that some portions of $A \beta$ are produced in vascular smooth muscle cells and that $A \beta$ is drained along ISF drainage pathways from brain parenchyma into vascular smooth muscle cell layers of cerebral vasculatures (Weller et al., 1998; Revesz et al., 2003; Thal et al., 2008), A $\beta$ clearance through vascular smooth muscle cells has received little attention compared with other brain cell types. If these vascular smooth muscle cell functions against $\mathrm{A} \beta$ were interfered, $\mathrm{A} \beta$ might accumulate in the brain, resulting in its deposition as senile plaques and CAA. In fact, risk factors of vascular diseases including diabetes mellitus, atherosclerosis, stroke, hypertension, transient ischemic attacks, and microvessel pathology are closely related to $\mathrm{AD}$ (de la Torre, 2002). Four risk factors (diabetes mellitus, hypertension, heart disease, and current smoking) have been reported to be associated with a higher risk of $\mathrm{AD}$ among individuals without dementia upon monitoring for a mean of 5.5 years (Luchsinger et al., 2005). Importantly, the risk of AD was significantly increased depending on the numbers of those four factors, where hazards ratios of probable and possible AD for the presence of one, two, three, or more risk factors were 1.7, 2.5, and 3.4 compared with no risk factors, respectively (Luchsinger et al., 2005). It is likely that impaired vascular function under these conditions further exacerbates amyloid and CAA pathology by reducing the efficiency of $A \beta$ clearance through LRP1-mediated pathway in brain vascular smooth muscle cells.

LRP1 is a multifunctional endocytic receptor involved in the metabolism of various extracellular ligands (Herz and Strickland, 2001; Bu, 2009). LRP1 is abundantly expressed in cerebrovascu- 
lar cells, in particular in vascular smooth muscle cells, as well as astrocytes, microglia (Marzolo et al., 2000), and neurons (Bu et al., 1994). Although it is still unclear whether LRP1 directly or indirectly mediates $A \beta$ clearance, the involvement of LRP1 in A $\beta$ metabolism in the brain is supported by findings that $A \beta$ clearance from the brain is inhibited by LRP1 antagonist, RAP, or antibodies against LRP1 in mice (Shibata et al., 2000). While several in vitro studies have shown that LRP1 in endothelial cells could mediate A $\beta$ transcytosis (Yamada et al., 2008; Pflanzner et al., 2011), there is no direct evidence to demonstrate that LRP1 in endothelial cells controls the elimination of $\mathrm{A} \beta$ at the bloodbrain barrier in vivo. Here, in this report, we demonstrated directly that a deletion of LRP1 in vascular smooth muscle cells disturbs its ability to mediate $\mathrm{A} \beta$ clearance through cellular uptake and degradation using both in vitro and in vivo models, suggesting that LRP1-mediated $A \beta$ clearance in vascular smooth muscle cells is critical for overall brain $\mathrm{A} \beta$ clearance by the cerebrovascular system. Consistent with our findings, Bell et al. (2009) have demonstrated that overexpression of serum response factor and myocardin in vascular smooth muscle cells suppressed $\mathrm{A} \beta$ clearance possibly through downregulation of LRP1.

LRP1 in vascular smooth muscle cells controls cellular uptake of $\mathrm{A} \beta$ and its subsequent trafficking to lysosome. Lysosomes contain a variety of acid hydrolases including cathepsin $\mathrm{B}$ and cathepsin D, which can efficiently degrade A $\beta$ (Nixon et al., 2001); however, when the lysosomal function is interfered or overwhelmed, $A \beta$ accumulation and aggregation are likely induced both in intracellular and extracellular space. Indeed, accumulation of $A \beta$ beyond the capacity of lysosomal function results in $\mathrm{A} \beta$ aggregation in the lysosomes, which can provide seeding for further $\mathrm{A} \beta$ aggregation ( $\mathrm{Hu}$ et al., 2009). A $\beta$ might be accumulated more in perivascular region if its drainage along the vasculature stagnates (Weller et al., 1998; Revesz et al., 2003; Thal et al., 2008). In general, the cerebroarterial pulsations are thought to mainly provide the driving force for drainage of ISF along the cerebrovasculature (Schley et al., 2006). Because LRP1 can function as a signal transducing receptor through coupling with other receptors (Herz and Strickland, 2001), it might be involved in controlling the homeostasis of cerebrovasculature. Thus, deletion of LRP1 in vascular smooth muscle cells may lead to A $\beta$ accumulation due to both a direct impairment of cellular $\mathrm{A} \beta$ uptake and lysosomal degradation and potential changes in overall vascular functions. Further studies are needed to address these possibilities.

Several pathological findings indicate that LRP1 levels are significantly decreased during aging and AD (Kang et al., 2000), in particular in brain vasculature (Bell et al., 2009). Hypoxia is one of the factors that suppress LRP1 expression in cerebral vessels (Bell et al., 2009). AD brains might be exposed to hypoxia due to decreased cerebral blood flow seen in AD patients. Toward this, we also found that hydrogen peroxide, a major reactive oxygen species, suppresses LRP1 expression in HBVSMCs (Fig. 8). Reactive oxygen species are excessively produced during aging, by inflammation, or upon $A \beta$ toxicity (Dumont and Beal, 2011). Therefore, aging or vascular damages may impair $\mathrm{A} \beta$ clearance by perturbing LRP1 expression and function in vascular smooth muscle cells, which leads to eventual $\mathrm{A} \beta$ accumulation and aggregation as senile plaques and CAA. Aging of cerebral arteries, $\mathrm{CAA}$, and apoE4 also impede perivascular drainage of solutes from the brain, which might further impair $A \beta$ clearance (Hawkes et al., 2011, 2012), although it is currently unclear whether LRP1 is involved in these processes.

Together, our findings provide novel insights into the molec- ular mechanisms of $\mathrm{AD}$ and $\mathrm{CAA}$, and suggest that restoring LRP1 expression in the brain vasculature in patients with $A D$ and CAA could be explored for therapy. Thus, it might be possible to screen for chemical compounds that can increase LRP1 expression and/or function in vascular smooth muscle cells. In fact, several compounds including rifampicin and caffeine seem to upregulate LRP1 expression and accelerate $\mathrm{A} \beta$ clearance in cerebrovasculature in mice (Qosa et al., 2012). These compounds can be explored as novel therapies for both $\mathrm{AD}$ and CAA.

\section{References}

Bell RD, Sagare AP, Friedman AE, Bedi GS, Holtzman DM, Deane R, Zlokovic BV (2007) Transport pathways for clearance of human Alzheimer's amyloid beta-peptide and apolipoproteins $\mathrm{E}$ and $\mathrm{J}$ in the mouse central nervous system. J Cereb Blood Flow Metab 27:909-918. CrossRef Medline

Bell RD, Deane R, Chow N, Long X, Sagare A, Singh I, Streb JW, Guo H, Rubio A, Van Nostrand W, Miano JM, Zlokovic BV (2009) SRF and myocardin regulate LRP-mediated amyloid-beta clearance in brain vascular cells. Nat Cell Biol 11:143-153. CrossRef Medline

Borchelt DR, Ratovitski T, van Lare J, Lee MK, Gonzales V, Jenkins NA, Copeland NG, Price DL, Sisodia SS (1997) Accelerated amyloid deposition in the brains of transgenic mice coexpressing mutant presenilin 1 and amyloid precursor proteins. Neuron 19:939-945. CrossRef Medline

$\mathrm{Bu}$ G (2009) Apolipoprotein E and its receptors in Alzheimer's disease: pathways, pathogenesis and therapy. Nat Rev Neurosci 10:333-344. CrossRef Medline

Bu G, Maksymovitch EA, Nerbonne JM, Schwartz AL (1994) Expression and function of the low density lipoprotein receptor-related protein (LRP) in mammalian central neurons. J Biol Chem 269:18521-18528. Medline

Bu G, Cam J, Zerbinatti C (2006) LRP in amyloid-beta production and metabolism. Ann N Y Acad Sci 1086:35-53. CrossRef Medline

Chakrabarty P, Ceballos-Diaz C, Beccard A, Janus C, Dickson D, Golde TE, Das P (2010) IFN-gamma promotes complement expression and attenuates amyloid plaque deposition in amyloid beta precursor protein transgenic mice. J Immunol 184:5333-5343. CrossRef Medline

Deane R, Wu Z, Sagare A, Davis J, Du Yan S, Hamm K, Xu F, Parisi M, LaRue B, Hu HW, Spijkers P, Guo H, Song X, Lenting PJ, Van Nostrand WE, Zlokovic BV (2004) LRP/amyloid beta-peptide interaction mediates differential brain efflux of Abeta isoforms. Neuron 43:333-344. CrossRef Medline

de la Torre JC (2002) Alzheimer disease as a vascular disorder: nosological evidence. Stroke 33:1152-1162. CrossRef Medline

Dumont M, Beal MF (2011) Neuroprotective strategies involving ROS in Alzheimer disease. Free Radic Biol Med 51:1014-1026. CrossRef Medline

El Khoury J, Luster AD (2008) Mechanisms of microglia accumulation in Alzheimer's disease: therapeutic implications. Trends Pharmacol Sci 29: 626-632. CrossRef Medline

Ellis RJ, Olichney JM, Thal LJ, Mirra SS, Morris JC, Beekly D, Heyman A (1996) Cerebral amyloid angiopathy in the brains of patients with Alzheimer's disease: the CERAD experience, Part XV. Neurology 46:15921596. CrossRef Medline

Goedert M, Spillantini MG (2006) A century of Alzheimer's disease. Science 314:777-781. CrossRef Medline

Hardy J, Selkoe DJ (2002) The amyloid hypothesis of Alzheimer's disease: progress and problems on the road to therapeutics. Science 297:353-356. CrossRef Medline

Hawkes CA, McLaurin J (2009) Selective targeting of perivascular macrophages for clearance of beta-amyloid in cerebral amyloid angiopathy. Proc Natl Acad Sci U S A 106:1261-1266. CrossRef Medline

Hawkes CA, Härtig W, Kacza J, Schliebs R, Weller RO, Nicoll JA, Carare RO (2011) Perivascular drainage of solutes is impaired in the ageing mouse brain and in the presence of cerebral amyloid angiopathy. Acta Neuropathol 121:431-443. CrossRef Medline

Hawkes CA, Sullivan PM, Hands S, Weller RO, Nicoll JA, Carare RO (2012) Disruption of arterial perivascular drainage of amyloid-beta from the brains of mice expressing the human APOE epsilon4 allele. PLoS One 7:e41636. CrossRef Medline

Herz J, Strickland DK (2001) LRP: a multifunctional scavenger and signaling receptor. J Clin Invest 108:779-784. CrossRef Medline

Holtwick R, Gotthardt M, Skryabin B, Steinmetz M, Potthast R, Zetsche B, 
Hammer RE, Herz J, Kuhn M (2002) Smooth muscle-selective deletion of guanylyl cyclase-A prevents the acute but not chronic effects of ANP on blood pressure. Proc Natl Acad Sci U S A 99:7142-7147. CrossRef Medline

Hu X, Crick SL, Bu G, Frieden C, Pappu RV, Lee JM (2009) Amyloid seeds formed by cellular uptake, concentration, and aggregation of the amyloid-beta peptide. Proc Natl Acad Sci U S A 106:20324-20329. CrossRef Medline

Kanekiyo T, Bu G (2009) Receptor-associated protein interacts with amyloid-beta peptide and promotes its cellular uptake. J Biol Chem 284: 33352-33359. CrossRef Medline

Kanekiyo T, Zhang J, Liu Q, Liu CC, Zhang L, Bu G (2011) Heparan sulphate proteoglycan and the low-density lipoprotein receptor-related protein 1 constitute major pathways for neuronal amyloid- $\beta$ uptake. J Neurosci 31:1644-1651. CrossRef Medline

Kang DE, Pietrzik CU, Baum L, Chevallier N, Merriam DE, Kounnas MZ, Wagner SL, Troncoso JC, Kawas CH, Katzman R, Koo EH (2000) Modulation of amyloid beta-protein clearance and Alzheimer's disease susceptibility by the LDL receptor-related protein pathway. J Clin Invest 106: 1159-1166. CrossRef Medline

Koffie RM, Hyman BT, Spires-Jones TL (2011) Alzheimer's disease: synapses gone cold. Mol Neurodegener 6:63. CrossRef Medline

Koistinaho M, Lin S, Wu X, Esterman M, Koger D, Hanson J, Higgs R, Liu F, Malkani S, Bales KR, Paul SM (2004) Apolipoprotein E promotes astrocyte colocalization and degradation of deposited amyloid-beta peptides. Nat Med 10:719-726. CrossRef Medline

Li Y, Lu W, Bu G (2003) Essential role of the low density lipoprotein receptor-related protein in vascular smooth muscle cell migration. FEBS Lett 555:346-350. CrossRef Medline

Liu Q, Zerbinatti CV, Zhang J, Hoe HS, Wang B, Cole SL, Herz J, Muglia L, Bu G (2007) Amyloid precursor protein regulates brain apolipoprotein $\mathrm{E}$ and cholesterol metabolism through lipoprotein receptor LRP1. Neuron 56:66-78. CrossRef Medline

Liu Q, Trotter J, Zhang J, Peters MM, Cheng H, Bao J, Han X, Weeber EJ, Bu G (2010) Neuronal LRP1 knockout in adult mice leads to impaired brain lipid metabolism and progressive, age-dependent synapse loss and neurodegeneration. J Neurosci 30:17068-17078. CrossRef Medline

Luchsinger JA, Reitz C, Honig LS, Tang MX, Shea S, Mayeux R (2005) Aggregation of vascular risk factors and risk of incident Alzheimer disease. Neurology 65:545-551. CrossRef Medline

Luo XG, Ding JQ, Chen SD (2010) Microglia in the aging brain: relevance to neurodegeneration. Mol Neurodegener 5:12. CrossRef Medline

Maia LF, Mackenzie IR, Feldman HH (2007) Clinical phenotypes of cerebral amyloid angiopathy. J Neurol Sci 257:23-30. CrossRef Medline

Marzolo MP, von Bernhardi R, Bu G, Inestrosa NC (2000) Expression of alpha(2)-macroglobulin receptor/low density lipoprotein receptorrelated protein (LRP) in rat microglial cells. J Neurosci Res 60:401-411. CrossRef Medline

Mawuenyega KG, Sigurdson W, Ovod V, Munsell L, Kasten T, Morris JC, Yarasheski KE, Bateman RJ (2010) Decreased clearance of CNS betaamyloid in Alzheimer's disease. Science 330:1774. CrossRef Medline

Miners JS, Van Helmond Z, Chalmers K, Wilcock G, Love S, Kehoe PG (2006) Decreased expression and activity of neprilysin in Alzheimer disease are associated with cerebral amyloid angiopathy. J Neuropathol Exp Neurol 65:1012-1021. CrossRef Medline

Nixon RA, Mathews PM, Cataldo AM (2001) The neuronal endosomallysosomal system in Alzheimer's disease. J Alzheimers Dis 3:97-107. Medline

Pflanzner T, Janko MC, Andre-Dohmen B, Reuss S, Weggen S, Roebroek AJ, Kuhlmann CR, Pietrzik CU (2011) LRP1 mediates bidirectional transcytosis of amyloid-beta across the blood-brain barrier. Neurobiol Aging 32:2323.e1-2323.e11. CrossRef Medline

Qiu Z, Strickland DK, Hyman BT, Rebeck GW (1999) Alpha2macroglobulin enhances the clearance of endogenous soluble betaamyloid peptide via low-density lipoprotein receptor-related protein in cortical neurons. J Neurochem 73:1393-1398. CrossRef Medline

Qosa H, Abuznait AH, Hill RA, Kaddoumi A (2012) Enhanced brain amyloid-beta clearance by rifampicin and caffeine as a possible protective mechanism against Alzheimer's disease. J Alzheimers Dis 31:151-165. CrossRef Medline

Rensink AA, de Waal RM, Kremer B, Verbeek MM (2003) Pathogenesis of cerebral amyloid angiopathy. Brain Res Brain Res Rev 43:207-223. CrossRef Medline

Revesz T, Ghiso J, Lashley T, Plant G, Rostagno A, Frangione B, Holton JL (2003) Cerebral amyloid angiopathies: a pathologic, biochemical, and genetic view. J Neuropathol Exp Neurol 62:885-898. Medline

Rohlmann A, Gotthardt M, Hammer RE, Herz J (1998) Inducible inactivation of hepatic LRP gene by cre-mediated recombination confirms role of LRP in clearance of chylomicron remnants. J Clin Invest 101:689-695. CrossRef Medline

Ruzali WA, Kehoe PG, Love S (2012) Influence of LRP-1 and apolipoprotein $\mathrm{E}$ on amyloid-beta uptake and toxicity to cerebrovascular smooth muscle cells. J Alzheimers Dis. Advance online publication. Retrieved October 14, 2012. doi:10.3233/JAD-2012-121336. CrossRef

Schley D, Carare-Nnadi R, Please CP, Perry VH, Weller RO (2006) Mechanisms to explain the reverse perivascular transport of solutes out of the brain. J Theor Biol 238:962-974. CrossRef Medline

Shibata M, Yamada S, Kumar SR, Calero M, Bading J, Frangione B, Holtzman DM, Miller CA, Strickland DK, Ghiso J, Zlokovic BV (2000) Clearance of Alzheimer's amyloid-ss(1-40) peptide from brain by LDL receptorrelated protein-1 at the blood-brain barrier. J Clin Invest 106:1489-1499. CrossRef Medline

Shinohara M, Sato N, Kurinami H, Takeuchi D, Takeda S, Shimamura M, Yamashita T, Uchiyama Y, Rakugi H, Morishita R (2010) Reduction of brain beta-amyloid (Abeta) by fluvastatin, a hydroxymethylglutaryl-CoA reductase inhibitor, through increase in degradation of amyloid precursor protein C-terminal fragments (APP-CTFs) and Abeta clearance. J Biol Chem 285:22091-22102. CrossRef Medline

Thal DR, Griffin WS, de Vos RA, Ghebremedhin E (2008) Cerebral amyloid angiopathy and its relationship to Alzheimer's disease. Acta Neuropathol 115:599-609. CrossRef Medline

Urmoneit B, Prikulis I, Wihl G, D’Urso D, Frank R, Heeren J, Beisiegel U, Prior R (1997) Cerebrovascular smooth muscle cells internalize Alzheimer amyloid beta protein via a lipoprotein pathway: implications for cerebral amyloid angiopathy. Lab Invest 77:157-166. Medline

Weller RO, Massey A, Newman TA, Hutchings M, Kuo YM, Roher AE (1998) Cerebral amyloid angiopathy: amyloid beta accumulates in putative interstitial fluid drainage pathways in Alzheimer's disease. Am J Pathol 153:725-733. CrossRef Medline

Wilhelmus MM, Otte-Höller I, van Triel JJ, Veerhuis R, Maat-Schieman ML, Bu G, de Waal RM, Verbeek MM (2007) Lipoprotein receptor-related protein-1 mediates amyloid-beta-mediated cell death of cerebrovascular cells. Am J Pathol 171:1989-1999. CrossRef Medline

Wyss-Coray T (2006) Inflammation in Alzheimer disease: driving force, bystander or beneficial response? Nat Med 12:1005-1015. Medline

Wyss-Coray T, Lin C, Yan F, Yu GQ, Rohde M, McConlogue L, Masliah E, Mucke L (2001) TGF-betal promotes microglial amyloid-beta clearance and reduces plaque burden in transgenic mice. Nat Med 7:612-618. CrossRef Medline

Wyss-Coray T, Loike JD, Brionne TC, Lu E, Anankov R, Yan F, Silverstein SC, Husemann J (2003) Adult mouse astrocytes degrade amyloid-beta in vitro and in situ. Nat Med 9:453-457. CrossRef Medline

Yamada K, Hashimoto T, Yabuki C, Nagae Y, Tachikawa M, Strickland DK, Liu Q, Bu G, Basak JM, Holtzman DM, Ohtsuki S, Terasaki T, Iwatsubo T (2008) The low density lipoprotein receptor-related protein 1 mediates uptake of amyloid beta peptides in an in vitro model of the blood-brain barrier cells. J Biol Chem 283:34554-34562. CrossRef Medline

Youmans KL, Leung S, Zhang J, Maus E, Baysac K, Bu G, Vassar R, Yu C, LaDu MJ (2011) Amyloid-beta42 alters apolipoprotein E solubility in brains of mice with five familial AD mutations. J Neurosci Methods 196: 51-59. CrossRef Medline

Zerbinatti CV, Wozniak DF, Cirrito J, Cam JA, Osaka H, Bales KR, Zhuo M, Paul SM, Holtzman DM, Bu G (2004) Increased soluble amyloid-beta peptide and memory deficits in amyloid model mice overexpressing the low-density lipoprotein receptor-related protein. Proc Natl Acad Sci U S A 101:1075-1080. CrossRef Medline

Zheng H, Koo EH (2011) Biology and pathophysiology of the amyloid precursor protein. Mol Neurodegener 6:27. CrossRef Medline

Zlokovic BV (2011) Neurovascular pathways to neurodegeneration in Alzheimer's disease and other disorders. Nat Rev Neurosci 12:723-738. CrossRef Medline 